\title{
Pseudolaric acid B inhibits the secretion of hepatitis B virus
}

\author{
JINGHUA YU ${ }^{1}$, ZENGYAN WANG $^{2}$, PEIYOU REN $^{3}$, TING ZHONG $^{4}$, YUE WANG $^{5}$, \\ FENGMEI SONG ${ }^{6}$, JINGWEI HOU ${ }^{1}$, XIAOYAN YU $^{6}$ and SHUCHENG HUA ${ }^{2}$
}

\begin{abstract}
${ }^{1}$ Institute of Virology and AIDS Research; Departments of ${ }^{2}$ Internal Medicine, and ${ }^{3}$ Thyroid Surgery, The First Hospital of Jilin University, Changchun, Jilin 130000; ${ }^{4}$ Medicinal Chemistry, and ${ }^{5}$ Chemistry of Traditional Chinese Medicine, College of Pharmacy, Changchun University of Chinese Medicine, Changchun, Jilin 130000; ${ }^{6}$ Department of Experimental Pharmacology and Toxicology, School of Pharmacy, Jilin Univrsity, Changhun, Jilin 130021, P.R. China
\end{abstract}

Received June 17, 2016; Accepted November 8, 2016

DOI: $10.3892 /$ or.2016.5254

\begin{abstract}
High hepatitis B virus (HBV) load and chronic hepatitis $\mathrm{B}$ infection increase the risk of developing hepatocellular carcinoma (HCC), and is also associated with recurrence of HBV-related HCC. The aim of the present study was to investigate whether pseudolaric acid $\mathrm{B}$ (PAB), a diterpene acid isolated from the root and trunk bark of Pseudolarix kaempferi Gordon (Pinaceae), has an inhibitory role on the HBV secretion in $\mathrm{HBV}$-related HCC. By detecting HBV surface antigen ( $\mathrm{HBsAg}$ ) by ELISA it was found that PAB inhibited HBV secretion in HepG2215 compared to control group, but did not decrease the intracellular HBV level, and the results were repeated in HepG2 cell transfect with HBV gene. Therefore, our results proved that PAB had the ability to inhibit HBV secretion. Moreover, it was shown that HepG2215 cells with HBV gene accumulated more in G0/G1 phase than HepG2 cells without HBV gene through detecting cell cycle distribution by flow cytometry, which indicated that HBV replication might favor the cell cycle environment of G0/G1 phase. However, HepG2 cells entered G2/M phase earlier than HepG2215 when PAB treatment induced G2/M arrest, therefore, HBV retarded the entry of G2/M to sustain the status of G0/G1 phase, while PAB finally changed the cell cycle environment favored by HBV virus. In addition, PAB also induced HepG2215 cell apoptosis, which would be helpful to kill the cells infected by HBV and help for devouring HBV by macrophage. Therefore, PAB inhibited HBV secretion through apoptosis and cell cycle arrest. The present findings contribute to a future potential chemotherapeutic drug in the treatment of HBV-related HCC.
\end{abstract}

Correspondence to: Professor Shucheng Hua, Department of Internal Medicine, The First Hospital of Jilin University, Jilin University, 71 Xinmin Street, Changchun, Jilin 130000, P.R. China E-mail: shuchenghua@eyou.com

Professor Xiaoyan Yu, Department of Experimental Pharmacology and Toxicology, School of Pharmacy, Jilin University, 1266 Fujin Road, Changchun, Jilin 130021, P.R. China

E-mail: yuxy@jlu.edu.cn

Key words: pseudolaric acid B, hepatocellular carcinoma, the secretion of hepatitis B virus, tumor growth

\section{Introduction}

Hepatocellular carcinoma (HCC) is one of the major health problems worldwide, ranking as the third leading cause of cancer-related mortality globally and the second in China (1). High hepatitis B virus (HBV) load and chronic hepatitis $B$ infection increase the risk of developing HCC (2), while high HBV viral load is also associated with recurrence for patients with hepatitis B virus-related HCC (HBV-related HCC) although the best therapeutic choices are early-stage tumors and preserved hepatic function, liver resection and liver transplantation $(3,4)$. Therefore, drug with both antitumor and anti-HBV effect will be important for patients with HBV-related HCC.

Natural products have played pivotal roles in the drug discovery and development process. This is particularly evident in the field of cancer therapeutics, where $>50 \%$ of the approved drugs introduced from 1981 to 2002 were of natural origin (5). It has been noted that natural products may embody more 'privileged structures' than purely synthetic chemical libraries (6) and they are a rich resource of new chemical motifs. Therefore, the natural product-based drug discovery program remains an important avenue toward the development of small-molecule therapeutics for cancer as well as other diseases (7). Pseudolaric acid B (PAB) is a novel diterpene acid isolated from the root bark of Pseudolarix kaempferi Gordon, known as 'Tu-Jin-Pi' Chinese herb, which has been safely used for centuries in traditional Chinese medicine for treating skin inflammation (8). PAB has antitumor effect through different mechanism in a number of cancer cell lines (8-13) which might be related to a unique polyhydroazulene with a trans substitution pattern at the junction sites which has not been found in any other natural products (14), however, it is still not known whether PAB possesses antiviral ability, especially anti-HBV.

In the present study, we confirmed that PAB had a new effect of inhibiting secretion of HBV and PAB was a candidate drug for anti-HBV and to treat HBV-related HCC.

\section{Materials and methods}

Materials. PAB, purchased from the National Institute for the Control of Pharmaceutical and Biological Products (Beijing, China), was dissolved in dimethyl sulfoxide (DMSO) to make 
a stock solution. DMSO concentration was kept below $0.01 \%$ in all the cell cultures, and did not exert any detectable effect on cell growth or cell death. Propidium iodode (PI), Hoechst 33258, RNase A and 3-(4,5-dimethylthiazol-2-yl)-2,5-diphenyltetrazolium bromide (MTT) were purchased from Sigma Chemical (St. Louis, MO, USA). Pro-caspase 3 antibody (SC-65497) and secondary antibodies (goat anti-rabbit or mouse) were obtained from Santa Cruz Biotechnology (Santa Cruz, CA, USA). Rabbit Histone H3 antibody (A01502-40) was from GenScript Corp. (Piscataway, NJ, USA). Diagnostic kit for hepatitis B virus surface antigen (ELISA) was from Shanghai Kehua Bio-Engineering, Co., Ltd. (Shanghai, China).

Cell culture. Human carcinoma HepG2 and HepG2215 were obtained from the American Type Culture Collection (ATCC; Manassas, VA, USA) and the cells were cultured in Dulbecco's modified Eagle's medium (DMEM; HyClone Laboratories, Logan, UT, USA) supplemented with $10 \%$ fetal calf serum (FBS; Gibco, Grand Island, NY, USA), and maintained at $37^{\circ} \mathrm{C}$ with $5 \% \mathrm{CO}_{2}$ in a humidified atmosphere.

Plasmid transfection and drug treatment. The pCMV ayw HBV proviral construct was previously described (15). Following the manufacturer's protocol of Lipofectamine 2000 , we transfect $1 \mu \mathrm{g}$ of plasmid together with $3 \mu \mathrm{l}$ of Lipofectamine 2000 (Invitrogen, Carlsbad, CA, USA) into cells in a 12-well plate, $12 \mathrm{~h}$ later, $4 \mu \mathrm{M}$ PAB were treated for $12 \mathrm{~h}$, then the supernatant or cells were collected for HBV surface antigen (HBsAg) detection.

HBsAg detection by ELISA. After $4 \mu \mathrm{M}$ PAB treatment for $12 \mathrm{~h}$, the cultured medium was examined for $\mathrm{HBV}$ surface antigen (HBsAg) with ELISA kits (Shanghai Kehua Bio-Engineering). The samples (50 $\mu \mathrm{l} /$ well) were incubated in the 96 -well microplate at $37^{\circ} \mathrm{C}$ for $1 \mathrm{~h}$, followed by $50 \mu \mathrm{l}$ horseradish peroxidase-conjugated primary antibodies for $30 \mathrm{~min}$, and then $50 \mu \mathrm{l}$ substrate for $10 \mathrm{~min}$ and then adding $50 \mu \mathrm{l}$ termination buffer to end the reaction. HBsAg in supernatants and cells are shown in the figures.

Flow cytometric analysis of cell cycle. HepG2215 cells or HepG2 cells $\left(1.0 \times 10^{6}\right)$ were harvested and rinsed with phosphate-buffered saline (PBS). The cell pellets were fixed in $70 \%$ ethanol at $4{ }^{\circ} \mathrm{C}$ overnight. After washing twice with PBS, the cells were stained with $1.0 \mathrm{ml}$ of PI solution containing PI $50 \mathrm{mg} / \mathrm{l}$, RNase A $1 \mathrm{~g} / \mathrm{l}$, and $0.1 \%$ Triton X-100 in sodium citrate $3.8 \mathrm{mM}$, followed by incubation on ice in the dark condition for $30 \mathrm{~min}$. The samples were analyzed by a FACScan flow cytometer (Becton Dickinson, Franklin Lakes, NJ, USA).

Observation of morphologic changes by light microscopy. HepG2215 cells $\left(5 \times 10^{5}\right.$ cells/well) were cultured in 6-wells plate for $24 \mathrm{~h}$. Then, $4 \mu \mathrm{M}$ PAB were treated for $0,6,12,24$ and $36 \mathrm{~h}$, morphologic changes were observed by phase contrast microscopy (Leica Biosystems GmbH, Nusslich, Germany).

Observation of nuclear morphologic changes. HepG2215 cells $\left(5 \times 10^{5}\right)$ were placed on the coverslips in a 6 -well plate.
After $24 \mathrm{~h}$ of cell culture, they were treated with $4 \mu \mathrm{M}$ PAB for $0,6,12,24$ and $36 \mathrm{~h}$, then were washed by PBS, fixed in $3.7 \%$ formaldehyde for $1 \mathrm{~h}$, then were stained with $5 \mathrm{mg} / \mathrm{l}$ Hoechst 33258 for $30 \mathrm{~min}$. Nuclear changes were observed by fluorescence microscopy at excitation wavelength $350 \mathrm{~nm}$ with emission filter $460 \mathrm{~nm}$ (Leica Biosystems $\mathrm{GmbH}$ ).

Determination of DNA fragmentation by agarose gel electrophoresis. Cells were trypsinized after PAB treatment for 0 , $6,12,24$ and $36 \mathrm{~h}$, and both adherent and floating cells were collected by centrifugation at $1,000 \mathrm{x} \mathrm{g}$ for $5 \mathrm{~min}$. It was done according to the protocol (12).

Western blot analysis of protein expression. Cells $\left(1 \times 10^{6}\right)$ were cultured in 25-ml culture bottle, and then were treated with $4 \mu \mathrm{M}$ PAB for $0,6,12,24$ and $36 \mathrm{~h}$. Both adherent and floating cells were collected and frozen at $-80^{\circ} \mathrm{C}$. Western blot analysis was performed for total proteins as follows (12).

Cell growth inhibition test. The inhibition of cell growth was determined by MTT test. HepG2 and HepG2215 cells $\left(1.0 \times 10^{4}\right.$ cells/well) were seeded into 96-well culture plates (Nunc A/S, Roskilde, Denmark). After 24 h of incubation, different concentration of PAB was added to the plates. Following incubation, cell growth was measured at different time-points by addition of $20 \mu \mathrm{l} 3$-(4,5-dimethylthiazol-2-yl)-2,5-diphenyltetrazolium bromide (MTT, $5 \mathrm{mg} / \mathrm{ml}$ ) at $37^{\circ} \mathrm{C}$ for $3 \mathrm{~h}$, and DMSO $(150 \mu \mathrm{l})$ was added to dissolve the formazan crystals. Absorbance was measured at $492 \mathrm{~nm}$ with enzyme-linked immunosorbent assay plate reader (Bio-Rad Laboratories, Hercules, CA, USA). The percentage of inhibition was calculated as follows: Inhibitory ratio $(\%)=\left[\mathrm{A}_{492}(\mathrm{control})-\mathrm{A}_{492}\right.$ (sample)]/[A $\mathrm{A}_{492}$ (control) - $\mathrm{A}_{492}$ (blank)] x $100 \%$.

Statistical analysis. All data represent at least three independent experiments, and are expressed as mean \pm SD. Statistical comparisons were made using the Student's t-test. P-values of $<0.001$ were considered to represent a statistically significant difference.

\section{Results}

$P A B$ inhibited the secretion of HBV in HepG2215 cell line. $\mathrm{HBV}$ secretion was related to ocurrence and recurrence of hepatocellular carcinoma $(3,4)$, so the present study detected the secretion of HBV after PAB treatment. Firstly, it was found that at $12 \mathrm{~h}$ PAB obviously decreased the level of $\mathrm{HBV}$ in supernatant through detecting $\mathrm{HBsAg}$, and supernatant $\mathrm{HBsAg}$ after PAB treatment was $69.17 \pm 2.81 \%$ of control group (Fig. 1A). Meanwhile it was also found that intracellular HBsAg was not affected obviously after PAB treatment compared to control group on condition that PAB group had the same cell number with control group (Fig. 1B). Therefore, PAB inhibited the secretion of $\mathrm{HBV}$ in HepG 2215 cell line.

$P A B$ inhibits the secretion of $H B V$ in HepG2 cell line transfected $H B V$ gene. For further confirming the effect of PAB on HBV secretion, we transfected HBV plasmid into HepG2 cells, and found that PAB also inhibited HBV secretion in 

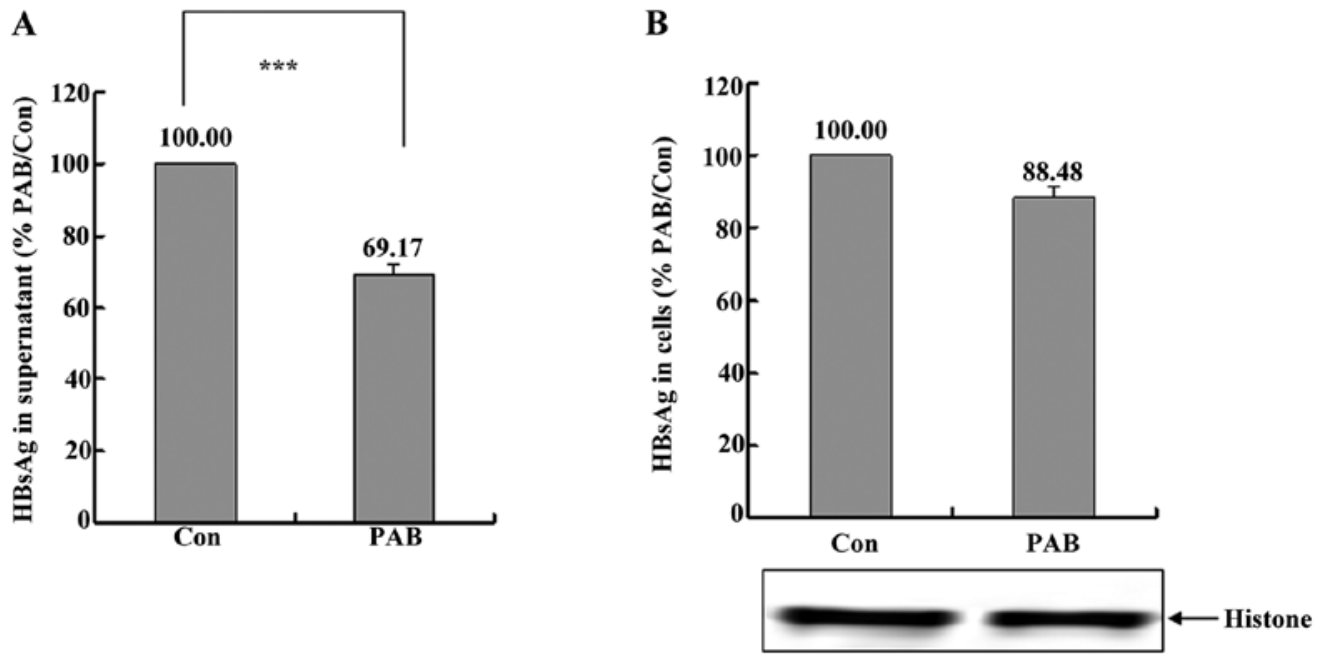

Figure 1. PAB inhibits HBV secretion in HepG2215. (A) At $12 \mathrm{~h}$ of $4 \mu \mathrm{M}$ PAB treatment, PAB decreased the level of HBV in the supernatant. (B) At $12 \mathrm{~h}$ of $4 \mu \mathrm{M}$ PAB treatment, PAB decreased intracellular HBV level, and western blot analysis analyzed the histone expression indicating the same cell numbers in control and PAB treatment group. The results are normalized to 1.0 in control cells. The results are representative of three independent experiments.
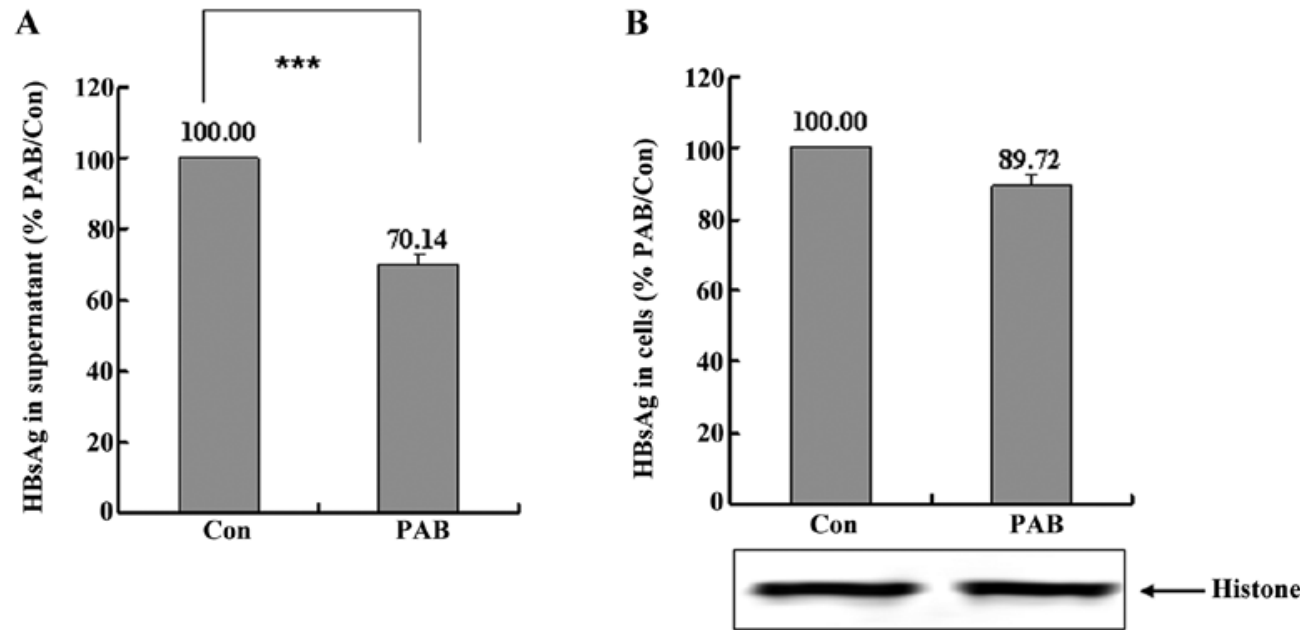

Figure 2. PAB inhibits HBV secretion in HepG2 transfect with HBV. (A) After $12 \mathrm{~h}$ of HBV transfection, PAB was used in treatment, then $12 \mathrm{~h}$ later, HBV in supernatant (A) and cells (B) were detected, and western blot analysis showed the histone expression indicating the same cell numbers in control and PAB treatment group. The results are normalized to $1.0 \mathrm{in} \mathrm{control} \mathrm{cells.} \mathrm{The} \mathrm{results} \mathrm{are} \mathrm{representative} \mathrm{of} \mathrm{three} \mathrm{independent} \mathrm{experiments.}$

transfect HepG2 cells, and supernatant HBsAg after PAB treatment was $70.14 \pm 2.84 \%$ of control group (Fig. $2 \mathrm{~A}$ ), and the inhibitory effect of PAB on intracellular HBsAg was not observed compared to control group as the PAB group had the same cell number than the control group (Fig. 2B). Therefore, PAB inhibited the secretion of HBV in HepG2 cell transfected HBV gene.

$P A B$ induces $G 2 / M$ arrest of HepG2 and HepG2215 cells. The drug affecting cell cycle status favored by virus inhibited viral production (16), so we detected cell cycle distribution after PAB treatment. After $4 \mu \mathrm{M}$ PAB treatment for $6,12,24$ and $36 \mathrm{~h}$, the DNA amount was obviously doubled compared with the control group in both HepG2 and HepG2215 cells, indicating the PAB-treated cells were arrested at the G2/M phase (Fig. 3). It was observed that more HepG2215 cells $(69.66 \pm 0.94 \%)$ arrested in G0/G1 phase than HepG2 cells $(62.3 \pm 1.98 \%)$ in normal situation. In addition, at $6 \mathrm{~h}$ of
PAB treatment, G0/G1 ratio of HepG2 and HepG2215 was $47.75 \pm 2.52$ and $63.2 \pm 1.12 \%$, respectively, while $\mathrm{G} 2 / \mathrm{M}$ ratio of HepG2 and HepG2215 was 50.79 \pm 2.36 and $22.16 \pm 1.30 \%$, respectively (Fig. 3B), indicating that $\mathrm{HBV}$ infection induced G0/G1 arrest, and G0/G1 arrest-induced by HBV retarded the entry of G2/M-induced by PAB. Therefore, PAB might affect cell cycle status favored by HBV to inhibit HBV secretion.

PAB induces apoptosis of HepG2215 cells. Cell apoptosis help to kill host cells of HBV (12), and macrophages to engulf apoptotic bodies (17) with HBV, thus, we detected the occurrence of apoptosis after PAB treatment. After $4 \mu \mathrm{M}$ PAB treatment for $12 \mathrm{~h}$, the number of floating cells was increased (upper panel of Fig. 4A) and the number of cells with bright blue condensed nuclei (low panel of Fig. 4A) were increased in HepG2215 cells. In addition, at 24 and $36 \mathrm{~h}$ after PAB treatment, there were obvious DNA ladder in agarose gel electrophoresis analysis of HepG2215 cells (Fig. 4B). The 
A

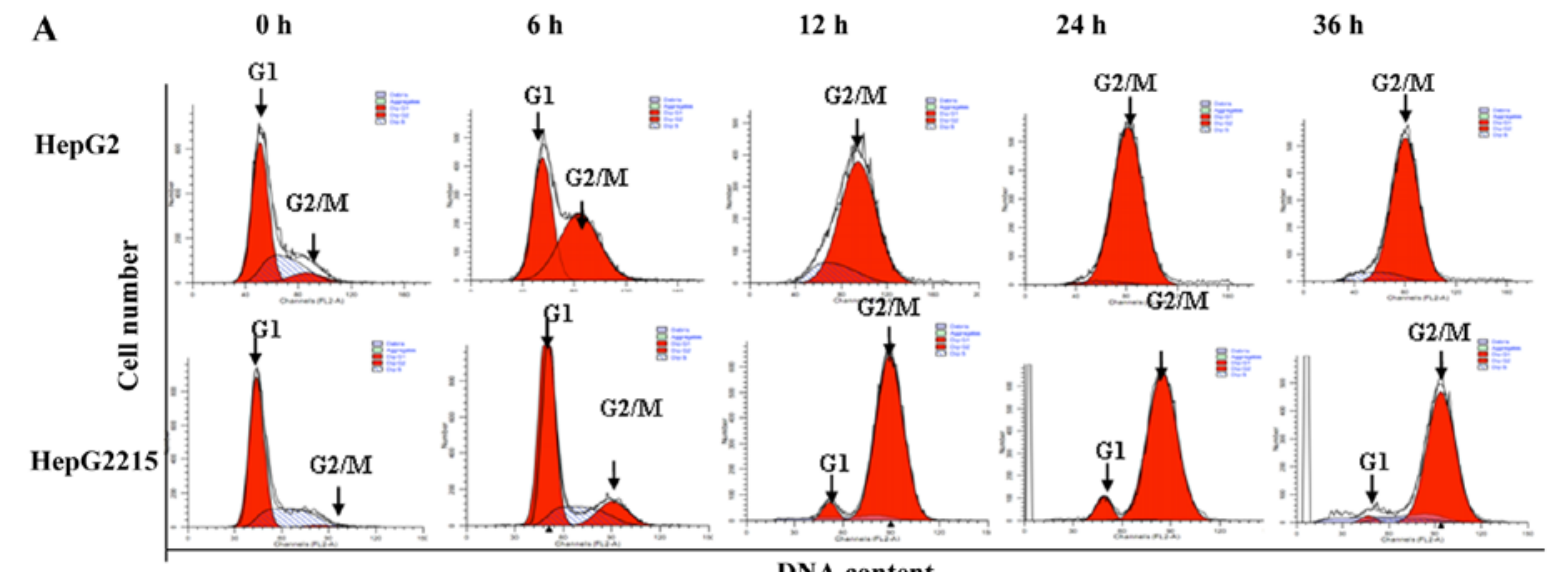

$6 \mathrm{~h}$

$12 \mathrm{~h}$

$24 \mathrm{~h}$

$36 \mathrm{~h}$

DNA content

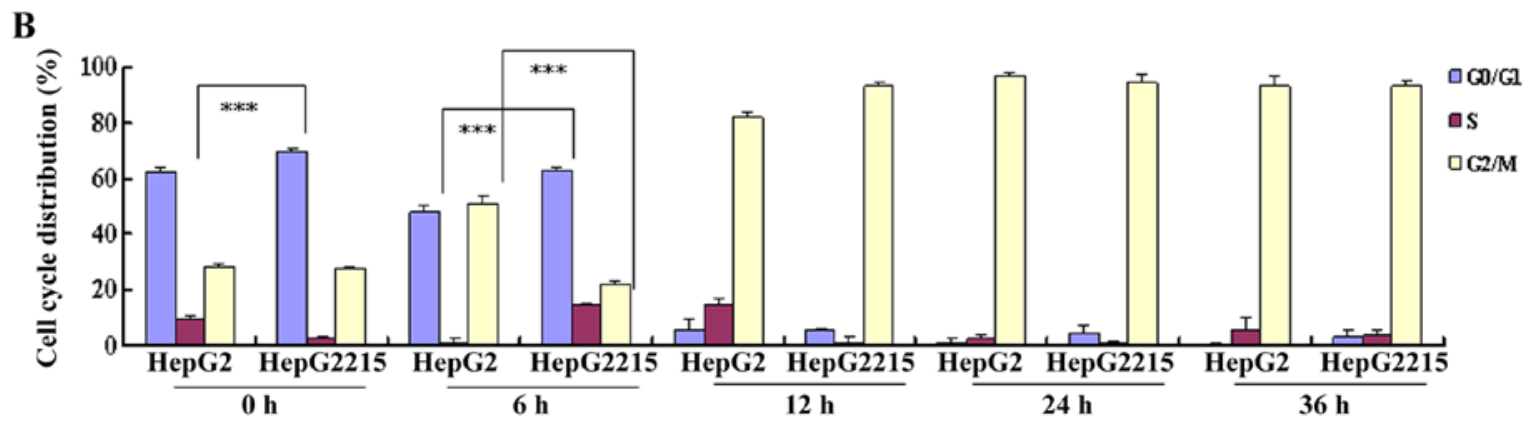

Figure 3. PAB promotes G2/M cell cycle arrest in HepG2 and HepG2215. (A) At different time-points, PAB induced obvious cell cycle arrest in HepG2 (upper panel) and HepG2215 (low panel). (B) Flow cytometric histogram analysis showed that from 6 to $36 \mathrm{~h}, 4 \mu \mathrm{M}$ PAB induced obvious cell cycle arrest. Mean \pm SD, $\mathrm{n}=3$.
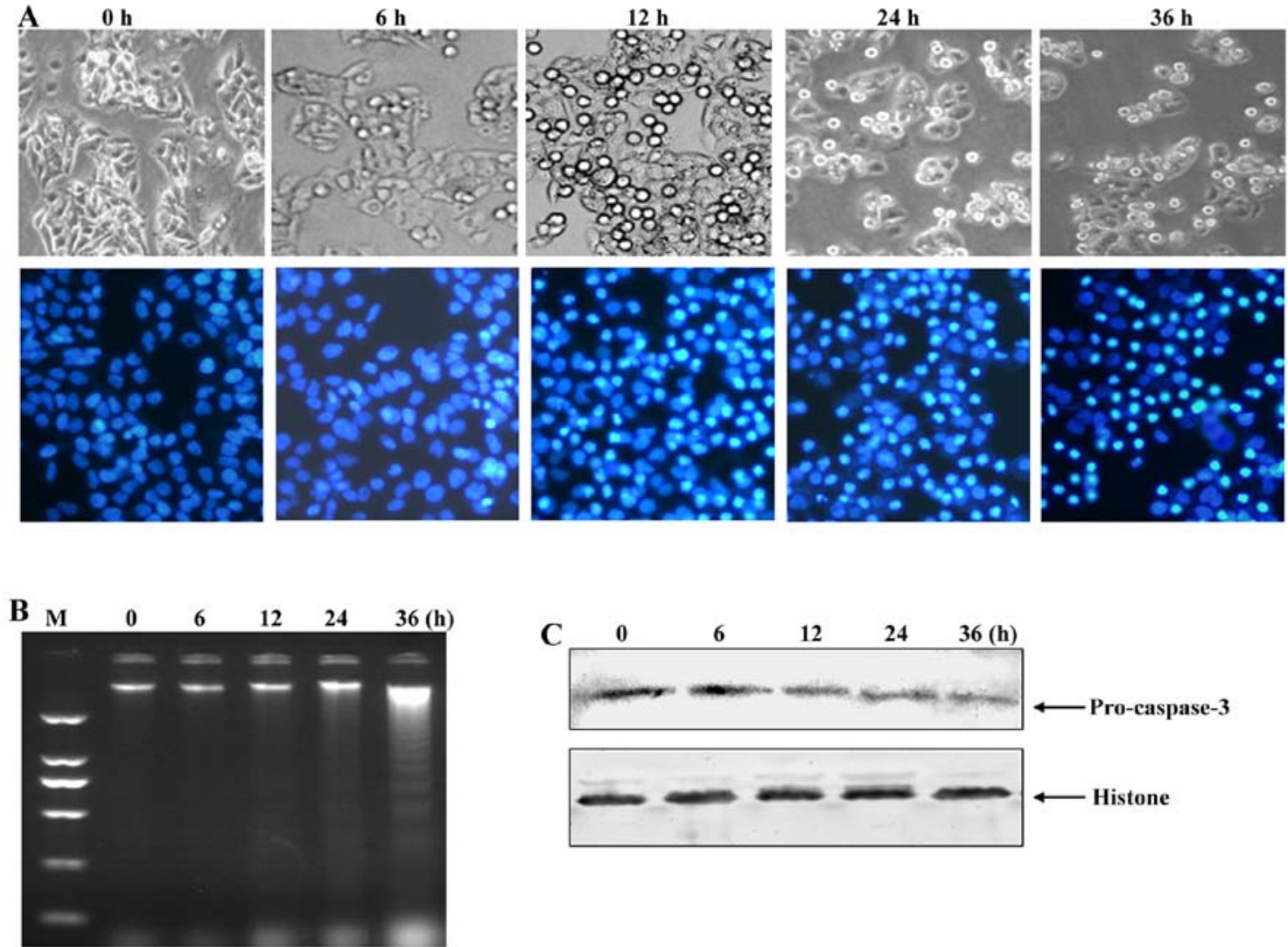

Figure 4. PAB induces apoptosis of HepG2215. After 0,6,12,24 and $36 \mathrm{~h}$ of $4 \mu \mathrm{M}$ PAB treatment, apoptotic markers were detected. (A) These cells were imaged via light microscopy for morphological changes and via fluorescence microscopy for nuclear changes after Hoechst 33258 staining. (B) The fragmentation of chromosomal DNA in PAB-treated cells determined by agarose gel electrophoresis. M indicated Marker. (C) The cells were lyzed and western blot analysis were performed for procaspase-3 protein expression. Data are presented of three individual experiments $(\mathrm{n}=3)$. Bar, $15 \mu \mathrm{m}$. 
A

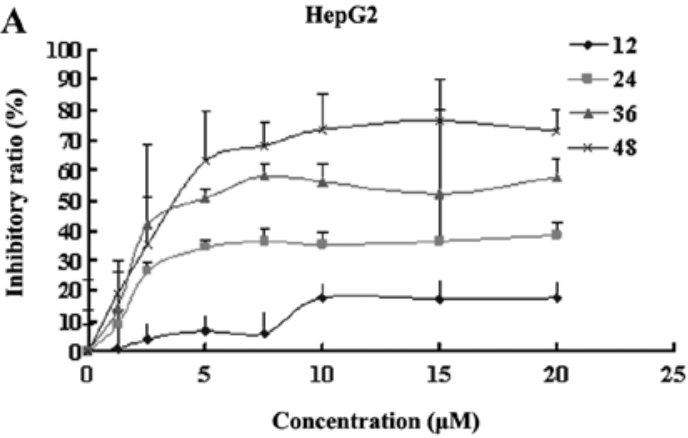

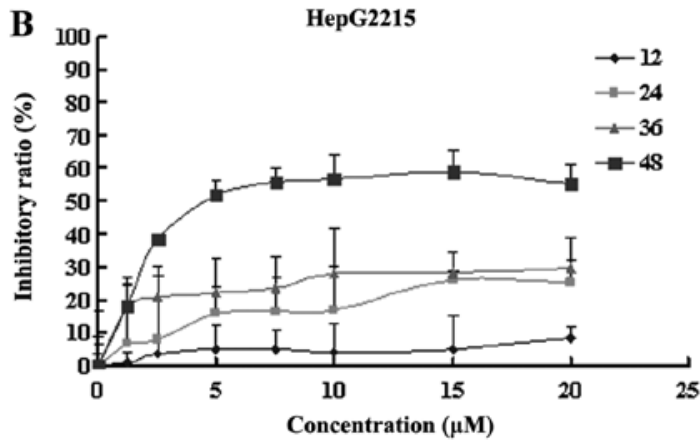

Figure 5. The inhibitory effect of PAB on HepG2 and HepG2215 cell growth at different time and dose. (A) The HepG2 cells (1x10 4 cells/well) were incubated with different doses of PAB for 12, 24, 36 and 48 h. (B) The HepG2215 cells (1x10 4 cells/well) were incubated with different doses of PAB for $12,24,36$ and $48 \mathrm{~h}$. Growth inhibition was evaluated by MTT method. Mean \pm SD, $\mathrm{n}=3$.

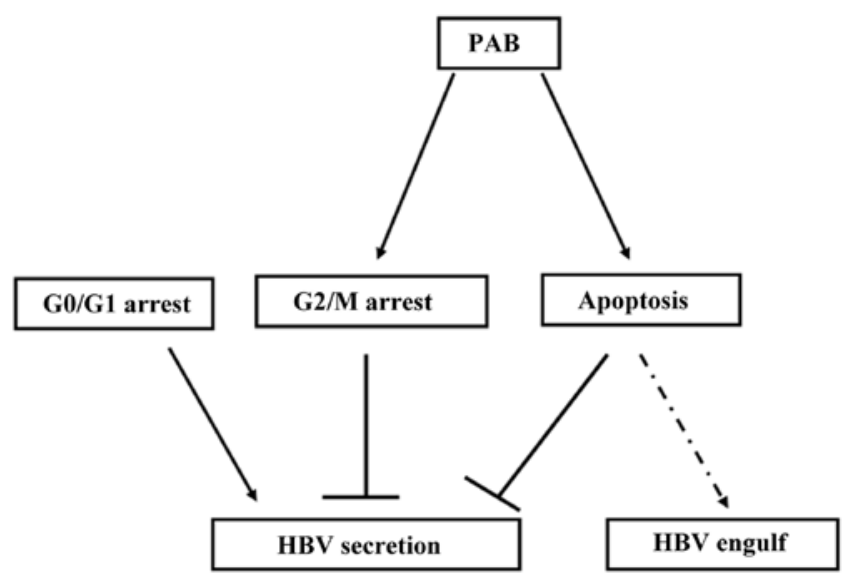

Figure 6. The mechanism of PAB inhibiting HBV secretion.

expression of procaspase-3 was decreased after PAB treatment in HepG2215 cells (Fig. 4C). Therefore, PAB induced apoptosis of HepG2215 cells.

The inhibitory effect of PAB on Hep G2 and Hep G2215 growth. To detect the growth inhibition of PAB-exposed HepG2 and HepG2215 cells to confirm the effect of HBV on the drug sensitivity, the cells were treated with various doses of PAB, from 0.4 to $20 \mu \mathrm{M}$ for $12,24,36$ and $48 \mathrm{~h}$. PAB showed potent suppressive effect on HepG2 (Fig. 5A) and HepG2215 (Fig. 5B) cells, and the $\mathrm{IC}_{50}$ values of PAB in HepG2 and HepG2215 cells at $36 \mathrm{~h}$ were 8.58 and $103.44 \mu \mathrm{M}$, at $48 \mathrm{~h}$ were 4.31 and $8.06 \mu \mathrm{M}$, respectively. Therefore, the cytotoxicity of PAB on HepG2 and HepG2215 cells was increased with the increased dose and time, and the inhibitory ratio of PAB on HepG2 was more obvious than HepG2215 (Fig. 6).

\section{Discussion}

Hepatocellular carcinoma (HCC) is a serious malignancy, and frequently found in refractory cancers in China, chronic infections of HBV could aid the development and recurrence of HCC $(3,4)$, and antivirus therapy would prevent development and recurrence of $\mathrm{HBV}$-related HCC. It was reported that pseudolaric acid $\mathrm{B}$ (PAB) possessed selective anti-proliferative effect in human cancer cells but not in normal cells in vitro and in vivo $(18,19)$, therefore, we investigated the effect of $\mathrm{PAB}$ on HBV secretion for HBV-related HCC treatment.

In the present study, HepG2215 cell line was used as a model to study HBV-related HCC because HepG2215 was stably transfected in the HBV genome into HepG2 cells (20), which is a widely used cell line in the study of the life cycle of HBV and antiviral research (21-23). In this study, PAB inhibited HBV secretion, but did not decrease the level of intracellular HBV in HepG2215, indicating that PAB had the ability of an anti-virus through inhibiting the HBV secretion. Furthermore, to confirm the effect of PAB on HBV secretion, we transfected HBV gene into HepG2 cell line, and we obtained similar results as in HepG2215, namely PAB inhibited HBV secretion. Therefore, it was concluded that PAB could inhibit HBV secretion.

As part of their pathogenic mechanism, many viruses facilitate their own growth by interacting with factors that regulate the host cell cycle. Examples can be found among DNA viruses, retroviruses and RNA viruses. For the DNA viruses, for example, some small DNA viruses such as simian virus $40(24)$, adenovirus $(25,26)$, and human papillomavirus (27), which lack their own polymerases, for using host polymerase promote the entrance of cells into the $S$ phase from the G1 phase. Other large DNA viruses, such as herpesviruses, can induce cell cycle arrest in the G0/G1 phase to avoid competition for cellular DNA replication resources (28). Besides the DNA viruses, cell cycle regulation has been observed for retroviruses (29,30). Furthermore, RNA viruses, for example infectious bronchitis virus (IBV) induces an $\mathrm{S}$ and G2/M-phase arrest to favor viral replication $(31,32)$. Then, we analyzed the inhibitory mechanism of PAB on HBV secretion on the cell cycle, it was found that more HepG2215 cells were in $\mathrm{G} 0 / \mathrm{G} 1$ phase than HepG2 from the analysis of the cell cycle, indicating that $\mathrm{HBV}$ induced G0/G1 arrest, which was consistent with a previous report (33). As through regulating the host cell cycle, virus replication could be affected (16), we analyzed whether PAB affected the status of cell cycle favored by HBV. In addition, it was confirmed that PAB induced $\mathrm{G} 2 / \mathrm{M}$ arrest in HepG2215 cells, which proved that PAB changed the cell cycle status favored by HBV. It was noted that at $6 \mathrm{~h}$ after PAB treatment, more HepG2 entered G2/M cell cycle than HepG2215, namely HepG2215 still stayed in G0/G1, indicating HBV struggled to let cells stay in G0/G1 phase after PAB treatment. 
Therefore, cell cycle arrest was a mechanism to inhibit HBV secretion.

Apoptosis is a mechanism to kill cancer cells, apoptotic cells were fragmented into apoptotic bodies which still had integrated membrane, and would be engulfed by macrophagy cells. We found that after PAB treatment, chromatin condensation, condensed cell floating, chromosomal DNA fragmentation and procaspase- 3 cleavage, all of which are apoptotic markers appeared in HepG2215 cells. It was speculated that HBV-related HCC cell apoptosis would be in favor of viral elimination because HBV virus was packaged in apoptotic bodies which was engulfed directly by immune cells, and HBV-related HCC cell apoptosis kill the host of HBV to eradicate HBV.

In addition, the present study found that $\mathrm{PAB}$ exerted potent inhibitory effect on HCC HepG2 cells and HBV-related HCC HepG2215 cells, and PAB had stronger inhibitory ability on HepG2 than HepG2215. Therefore, it is speculated that HBV infection endowed cancer cells drug tolerance to some extent.

The detailed mechanism of PAB of anti-HBV is still not clear, but it was speculated that: i) PAB as a depolymerization of tubulin drug inhibited the polymerization of tubulin (34) which was important for HBV production and secretion; ii) PAB induced G2/M cell cycle arrest, but G0/G1 arrest was required by HBV secretion; and iii) $\mathrm{PAB}$ induced apoptosis which could damage some important proteins, organelles, or others that were required for secretion and thus apoptosis would be in favor of engulfing the virus by macrophages.

Uncovering the phenomenon of PAB inhibiting HBV secretion might lead to its use as an anticancer treatment of HBV-related HCC.

\section{Acknowledgements}

The present study was supported by funding from the National Natural Science Foundation of China (81301416), the Postdoctoral Science Foundation of China (2014M561302, 2015T80299), the Norman Bethune Program of Jilin University (2015202), the Jilin Provincial Science and Technology Department (20140204004YY and 20160414025GH), and the Department of Human Resources and Social Security of Jilin Province (2016014).

\section{References}

1. Hadziyannis SJ, Tassopoulos NC, Heathcote EJ, Chang TT, Kitis G, Rizzetto M, Marcellin P, Lim SG, Goodman Z, Ma J, et al; Adefovir Dipivoxil 438 Study Group: Long-term therapy with adefovir dipivoxil for HBeAg-negative chronic hepatitis B for up to 5 years. Gastroenterology 131: 1743-1751, 2006.

2. Sangiovanni A, Del Ninno E, Fasani P, De Fazio C, Ronchi G, Romeo R, Morabito A, De Franchis R and Colombo M: Increased survival of cirrhotic patients with a hepatocellular carcinoma detected during surveillance. Gastroenterology 126: 1005-1014, 2004.

3. Bruix $\mathrm{J}$ and Sherman M; Practice Guidelines Committee, American Association for the Study of Liver Diseases: Management of hepatocellular carcinoma. Hepatology 42: 1208-1236, 2005.

4. Sherman M: Recurrence of hepatocellular carcinoma. N Engl J Med 359: 2045-2047, 2008.

5. Newman DJ, Cragg GM and Snader KM: Natural products as sources of new drugs over the period 1981-2002. J Nat Prod 66 1022-1037, 2003.
6. Breinbauer R, Vetter IR and Waldmann H: From protein domains to drug candidates-natural products as guiding principles in the design and synthesis of compound libraries. Angew Chem Int Ed Engl 41: 2879-2890, 2002.

7. Mann J: Natural products in cancer chemotherapy: Past, present and future. Nat Rev Cancer 2: 143-148, 2002.

8. Zhou BN, Ying BP, Song GQ, Chen ZX, Han J and Yan YF: Pseudolaric acids from Pseudolarix kaempferi. Planta Med 47: 35-38, 1983.

9. Gong X, Wang M, Tashiro S, Onodera S and Ikejima T: Involvement of JNK-initiated p53 accumulation and phosphorylation of p53 in pseudolaric acid B induced cell death. Exp Mol Med 38: 428-434, 2006.

10. Gong XF, Wang MW, Tashiro S, Onodera S and Ikejima T: Pseudolaric acid B induces apoptosis through p53 and Bax/ Bcl-2 pathways in human melanoma A375-S2 cells. Arch Pharm Res 28: 68-72, 2005.

11. Yu J, Li X, Tashiro S, Onodera S and Ikejima T: Bcl-2 family proteins were involved in pseudolaric acid B-induced autophagy in murine fibrosarcoma L929 cells. J Pharmacol Sci 107: 295-302, 2008.

12. Yu JH, Cui Q, Jiang YY, Yang W, Tashiro S, Onodera S and Ikejima T: Pseudolaric acid B induces apoptosis, senescence, and mitotic arrest in human breast cancer MCF-7. Acta Pharmacol Sin 28: 1975-1983, 2007.

13. Yu JH, Wang HJ, Li XR, Tashiro S, Onodera S and Ikejima T: Protein tyrosine kinase, JNK, and ERK involvement in pseudolaric acid B-induced apoptosis of human breast cancer MCF-7 cells. Acta Pharmacol Sin 29: 1069-1076, 2008.

14. Ma G, Chong L, Li XC, Khan IA, Walker LA and Khan SI: Selective inhibition of human leukemia cell growth and induction of cell cycle arrest and apoptosis by pseudolaric acid B. J Cancer Res Clin Oncol 136: 1333-1340, 2010.

15. Xu R, Zhang X, Zhang W, Fang Y, Zheng S and Yu XF: Association of human APOBEC 3 cytidine deaminases with the generation of hepatitis virus $\mathrm{B} x$ antigen mutants and hepatocellular carcinoma. Hepatology 46: 1810-1820, 2007.

16. Yu J, Zhang L, Ren P, Zhong T, Li Z, Wang Z, Li J, Liu X, Zhao K, Zhang W, et al: Enterovirus 71 mediates cell cycle arrest in $\mathrm{S}$ phase through non-structural protein 3D. Cell Cycle 14: 425-436, 2015.

17. Sciorati C, Rigamonti E, Manfredi AA and Rovere-Querini P: Cell death, clearance and immunity in the skeletal muscle. Cell Death Differ 23: 927-937, 2016.

18. Khan M, Zheng B, Yi F, Rasul A, Gu Z, Li T, Gao H, Qazi JI, Yang $\mathrm{H}$ and Ma T: Pseudolaric Acid B induces caspase-dependent and caspase-independent apoptosis in $\mathrm{u} 87$ glioblastoma cells. Evid Based Complement Alternat Med 2012: 957568, 2012.

19. Wong VK, Chiu P, Chung SS, Chow LM, Zhao YZ, Yang BB and Ko BC: Pseudolaric acid B, a novel microtubule-destabilizing agent that circumvents multidrug resistance phenotype and exhibits antitumor activity in vivo. Clin Cancer Res 11: 6002-6011, 2005.

20. Sells MA, Chen ML and Acs G: Production of hepatitis B virus particles in Hep G2 cells transfected with cloned hepatitis B virus DNA. Proc Natl Acad Sci USA 84: 1005-1009, 1987.

21. Ding XR, Yang J, Sun DC, Lou SK and Wang SQ: Whole genome expression profiling of hepatitis B virus-transfected cell line reveals the potential targets of anti-HBV drugs. Pharmacogenomics J 8: 61-70, 2008.

22. Li GQ, Xu WZ, Wang JX, Deng WW, Li D and Gu HX: Combination of small interfering RNA and lamivudine on inhibition of human B virus replication in HepG2.2.15 cells. World J Gastroenterol 13: 2324-2327, 2007.

23. Xin XM, Li GQ, Guan XR, Li D, Xu WZ, Jin YY and Gu HX: Combination therapy of siRNAs mediates greater suppression on hepatitis B virus cccDNA in HepG2.2.15 cell. Hepatogastroenterology 55: 2178-2183, 2008.

24. DeCaprio JA, Ludlow JW, Figge J, Shew JY, Huang CM, Lee WH, Marsilio E, Paucha E and Livingston DM: SV40 large tumor antigen forms a specific complex with the product of the retinoblastoma susceptibility gene. Cell 54: 275-283, 1988.

25. Eckner R, Ewen ME, Newsome D, Gerdes M, DeCaprio JA, Lawrence JB and Livingston DM: Molecular cloning and functional analysis of the adenovirus E1A-associated $300-\mathrm{kD}$ protein (p300) reveals a protein with properties of a transcriptional adaptor. Genes Dev 8: 869-884, 1994. 
26. Howe JA, Mymryk JS, Egan C, Branton PE and Bayley ST: Retinoblastoma growth suppressor and a 300-kDa protein appear to regulate cellular DNA synthesis. Proc Natl Acad Sci USA 87: 5883-5887, 1990.

27. Werness BA, Levine AJ and Howley PM: Association of human papillomavirus types 16 and 18 E6 proteins with p53. Science 248: 76-79, 1990.

28. Flemington EK: Herpesvirus lytic replication and the cell cycle: Arresting new developments. J Virol 75: 4475-4481, 2001.

29. Goh WC, Rogel ME, Kinsey CM, Michael SF, Fultz PN, Nowak MA, Hahn BH and Emerman M: HIV-1 Vpr increases viral expression by manipulation of the cell cycle: A mechanism for selection of Vpr in vivo. Nat Med 4: 65-71, 1998.

30. He J, Choe S, Walker R, Di Marzio P, Morgan DO and Landau NR: Human immunodeficiency virus type 1 viral protein $\mathrm{R}$ (Vpr) arrests cells in the G2 phase of the cell cycle by inhibiting p34cdc2 activity. J Virol 69: 6705-6711, 1995.
31. Dove B, Brooks G, Bicknell K, Wurm T and Hiscox JA: Cell cycle perturbations induced by infection with the coronavirus infectious bronchitis virus and their effect on virus replication. J Virol 80: 4147-4156, 2006.

32. Li FQ, Tam JP and Liu DX: Cell cycle arrest and apoptosis induced by the coronavirus infectious bronchitis virus in the absence of p53. Virology 365: 435-445, 2007.

33. Wang T, Zhao R, Wu Y, Kong D, Zhang L, Wu D, Li C, Zhang C, Yu Z and Jin X: Hepatitis B virus induces G1 phase arrest by regulating cell cycle genes in HepG2.2.15 cells. Virol J 8: 231, 2011.

34. Tong YG, Zhang XW, Geng MY, Yue JM, Xin XL, Tian F, Shen X, Tong LJ, Li MH, Zhang C, et al: Pseudolarix acid B, a new tubulin-binding agent, inhibits angiogenesis by interacting with a novel binding site on tubulin. Mol Pharmacol 69: 1226-1233, 2006. 